\title{
Sustaianable development and environmental policy: the engagement of stakeholders in green products in Vietnam
}

\author{
Quang Le Van, Manh-Hung Nguyen and Nguyen Viet Thanh
}

\begin{abstract}
Facing the challenge of environmental degradation in Vietnam, a growing number of firms have begun to integrate environmental management systems into their business strategies and develop green product diversification strategies. Based on the stakeholder theory, this paper attempts to explore the influences of stakeholders on the implementation of horizontal and vertical green product diversification. Empirical results show that foreign customers play a significant role in driving companies to adopt strategy of green product diversification. For foreign-invested enterprises, the effect is limited to the adoption of horizontal green product diversification. It further reveals thatInstitutional weakness, lack of transparency, community stakeholders and regulatory stakeholders have no significant effect on the corporate green product strategy.
\end{abstract}

Key words: SMEs, green products, diversification, stakeholders, and environmental management

\section{Introduction}

With the advent of severe environmental deterioration, green product development strategy has received increasing attention and is being thought of as an essential path to achievefirms' environmental sustainability (Crowe and Brennan, 2007; Bos-Brouwers, 2010; Hall and Wagner, 2011). There is increasing social and political awareness of the importance of developing environmental responsibility at corporate level (Babiak and Trendafilova, 2011). A green product is a product whose design and/or attributes (and/or production and/or strategy) use recycling (renewable/toxic-free/biodegradables) resources and which improves environmental impact or reduces environmental toxic damage throughout its entire life cycle. (Durif, Boivin, Julien (2010). In the literature, green product terminology often refers to "green innovations" (e.g., Chen, Lai and Wen, 2006), "eco-efficiency product" (e.g., Parthasarathy et al., 2005; Magerholm, 2003), "environmentally product" (e.g., Pickett-Baker and Ozaki, 2008), "environmental innovation" (e.g., Triebswetter and Wackerbauer, 2008; Wagner, 2000). Corporate Environmental Responsibility (CER) can be defined as company practices that benefit the environment and go beyond simply complying with environmental laws (Gunningham, 2009). When focusing on issues of responsibility, large companies are 
frequently perceived to be more responsible for driving climate change and resource depletion (Cassells and Lewis, 2011), that is, there is a misconception that small and medium-sized firms (SMEs) (following the definition of the Wold Bank, an SME having fewer than 300 employees) are less aware of the negative effects of their operations and lack interest in pursuing environmental practices (Cassells,Lewis,2011; Baumann-Pauly and al, 2013). Furthermore, SMEs provide little information regarding their strategies and financial performance and, therefore, this contributes to their being less studied (Bos-Brouwers, 2010).

It is often unclear that SMEs, unlike large companies, maintain a close relationship with their community (internal and external stakeholder). For Csikszentmihalyi (1997) creativity is the result of an interaction between the context, the individual and the collective. These factors favor creativity in the company (Bessant and Tidd, 2007, p.40). These three main concepts are very present and important in SMEs. Because of its limited resources, according to Carrier (2007, p.120), SMEs must mobilize the creative strength of each of their employees (who indicate the individual), their teams (which indicate the collective) and actors in its environment (which indicate the context). Moreover, another SME asset is its organizational flexibility, that is, it has a "simple and little hierarchical structure [....] where relationships are often informal" (Carrier, 2007). Because of this flexibility, individuals can work with different groups inside and outside (Georgsdottir et al., 2003, p.182). It allows the SME to adapt quickly to changes and make quick decisions. This is possible because, thanks to its flexibility, it has access to information sources and new ideas. It therefore favors the diversification of products.

The drivers for green product diversification are multiple (Nameroff et al., 2004; Frondel et al., 2007; Horbach, 2008; González, 2009), in which stakeholders' roles are different (Wagneret al., 2002; Triebswetter and Wackerbauer, 2008; Babiak and Trendafilova, 2011). These stakeholders include regulation stakeholders, customers, investors, and so on (Frooman, 1999; Henriques and Sadorsky, 1999; Buysse and Verbeke, 2003; Pfeffer and Salancik, 2003; Sharma and Henriques, 2005; Murillo-Lunaet al., 2008; Qi et al., 2010). Researchers have found evidence that pressure from stakeholders is distinguished as a determinant factor for firms' green products decision (Amaeshi and Crane, 2006; GonzálezBenito and González-Benito, 2006; Ditlev-Simonsen and Midttun, 2011; Hall and Wagner, 2011). It was revealed that regulations, for example, play a key role in green production innovation (Nameroffet al., 2004; Horbach, 2008; Kammerer, 2009). Customer demand for green products is also a driver in encouraging the adoption of green products practices by firms (Christmann and Taylor, 2001; Coleet al., 2005; Albornozet al., 2009; Perkins and 
Neumayer, 2009). Investor influence on firms' environmental practice has also been recognized (Bansal and Roth, 2000). Researchers found that the environmental preference of community stakeholders might affect firms' environmental behavior (Sharma and Henriques, 2005; Kassinis and Vafeas, 2006). The Top Management Team has an important role in defining the environmental orientation of the firm, since their values and environmental orientation determine to a great extent the corporate responsibility assumed and the environmentally practices implemented by the firm (Menon, 1997).

However, many empirical studies use a single dimension to measure green product diversification: Popp (2005) used patents and Frondelet al. (2008) used ABATE (an indicator of significant changes in production technologies). They did not discriminate horizontal green products diversification from vertical green products diversification. Although there is a relationship between hozontal and vertical green products diversification (Henriques and Sadorsky, 2007), it was argued that the underling drivers for green products diversification are heterogeneous. Hence, studies on green products diversification should be carried out under an integral framework (Tang, 1998; Henriques and Sadorsky, 2007, 2011; Frondelet al., 2008).

This study is rooted in stakeholder theory (Freeman, 1984), assuming that increased ecological sensitivity from internal and external stakeholders leads a firm towards higher responsiveness to environmental concerns. And it aims also to provide a background on environmental management in Vietnam, where widespread concerns in interpreting the drivers for horizontal and vertical green products diversification have been raised (Kalinichuk, 2013; Raudszus, 2014). Since the 2000s, the Vietnamese economy has been experiencing dynamic economic growth, driven by emergence of private sector, international trade and foreign investment. The country experienced a growth rate of $7 \%$ during the two past decades. It allows Vietnam to move out of the group of low-income countries. However, the economic growth causes water and air pollutions and the higher intensity of natural resource exploitation (UNIDO, 2012; WB, 2011). The World Bank (WB, 2011) shows increasing utilization of natural resources such as land, water, and energy. air pollution augmented significantly along with GDP growth. The $\mathrm{CO} 2$ emission has also soared five folds during 1990-2007. Vietnam's economic growth has put negative impacts to the environment and there was trade-off between these two pillars of sustainable development (WB, 2011). MONRE (2010) indicates that water pollution in most of all rivers, ponds, channels in urban areas was serious, mainly due to organic substances. Almost all of 
Vietnam's sea areas have the oil content surpassed the ASEAN's standard for the aquatic conservation water (MONRE, 2010). Vietnam ranked 136 among 178 countries for the Environmental Performance Index (EPI) in 2014 (the worst component index was related to water, forest and fisheries resources) (Hsu et al., 2014). The fast economic growth in Vietnam has greatly relied on the extensive expansion of manufacturing industries which produce resource-intensive but cheap goods for foreign markets. The main contribution of this study is to multi-dimensionally explore the heterogonous effects of stakeholder pressure on the strategic choice of green products diversification for Vietnamess SMEs. This understanding could facilitate mechanisms that foster green innovation, allowing researchers, managers, and policymakers to determine the relative efficacy of different stakeholders on driving green products diversification.

\section{Theoretical Framework and Hypotheses development}

\subsection{Green product diversification}

In our paper, the green product is defined as a product which, by its design, its composition, and / or by its production process, respects the environment throughout its life and which is identifiable and differentiable compared to conventional products in the eyes of consumers. The concept of green products in the commercial environment is associated with the realization of something new or different (Garcia and Calantone, 2002). Thus, Companies that wish to communicate to customers that their products are eco-friendly can do so by getting a green certification from an independent, third party and labeling their products as environmentally sound. There are numerous third parties that have been recognized as a reliable source for obtaining an eco-label for products, including the following: German Blue Angel, the US Green Seal, the Nordic Council White Swan, the Canadian Environmental Choice, the European Eco-Label, the Japan Eco Mark , FSC, NF environment, AB. The literature on the green product diversification seems to have overlooked the fact that product diversification have two dimensions. A change may be vertical, resulting in quality improvement or deterioration, or it may be horizontal, involving an increase or decreasein the number of sizes, colors, and shapes in which the product is made.

However, whether a product is green constitutes a complex issue and is often the subject of debate (Dangelico and Pujari, 2010; Schiederig and al., 2012). Products that are claimed to have « environmental benefits » possess - more often than not - no such qualities, but they are 
simply less harmful to the natural environment than others (Ottman and al., 2006). Therefore, green products are here in defined as products whose greenness is significantly better than conventional or competitive products. Greenness is continuous rather than dichotomous (Schiederig and al., 2012): "green » products represent a significant improvement in greenness, which can be either small or large, whereas "non-green" refers to no or an insignificant improvement in greenness. Greenness consists of many underlying qualities (Dangelico and Pontrandolfo, 2010; Mangunand and Thurston, 2002)

The environmental impact of products occurs across three dimensions: materials, energy and pollution (Dangelico and Pontrandolfo, 2010). In each of the three dimensions, the environmental impact may be reduced, or a positive contribution may be realized (Dangelico and Pontrandolfo, 2010). In this paper, we consider a product diversification to be "green" if it performs better on any or a combination of the three dimensions compared to conventional or competitive products. So green product diversification includes horizontal and vertical green product diversification, which relate to technological, organizational, social, or institutional changes contributing to a reduction of environmental burdens from the production process and products (Rennings, 2000; Chenet al., 2006).

\section{Horizontal green product diversification}

In line whit the above notion of green product diversification, the horizontal green product diversification could be defined as a mechanism in which firms making these goods are incorporating environmental product attributes into the over all product mix and not simply "tacking them on" to existing products as an after thought (ex-ante but not ex-post). The characteristics of green product, in fact, can be communicated externally through ecolabeling (Albino et al., 2009). With the increasing demand for green products, eco-labeling can serve as an instrument for stakeholders to recognize the environmental characteristics of products. Given the complex nature of the environmental impact of products along their life cycle, eco-labeling can reduce asymmetric information among stakeholders (Gallastegui, 2002; Pujari, 2006), help companies toward environmental sustainability, and enhance their competitive advantage (Pujari et al., 2003; Dangelico and Pujari, 2010). In this way, the firms are making en vironmental objectives as important as "other" financial objectives (i.e.profitability, market share, etc.). Firms are finding that "going green" makes good business sense as well as good environmental sense (Menon and Menon, 1997, Porter and van der Linde, 1995). 


\section{Vertical green product diversification}

The vertical green product diversification consist to produce new green products thank to green process innovation. It's used as an instrument to improve firms' environmental management process (Chen et al., 2006), allowing the industrial production process to realize the environmental sustainability vision and the potentialities of eco-efficiency (Porter and Van der Linde, 1995; Hart and Ahuja, 1996). Issued by the International Organization for Standardization (ISO) in 1996, ISO 14001 has been steadily and increasingly adopted and has become the most recognized environmental management program in the world (Nishitani, 2009). The implementation of ISO 14001 certification can bring about reduction in firms' environmental impact, improvement of operational efficiency and effectiveness (Jiang and Bansal, 2003; King et al., 2005), and signal to external stakeholders afirm's environmental commitment (Johnstone and Labonne, 2009; Nishitani, 2009). Stakeholder pressure attaches an important weight to firms' adoption of ISO 14001 (Delmas and Toffel, 2004; Johnstone and Labonne, 2009; Takahashi and Nakamura, 2010). In this study, ISO 14001 certification is used as a measurement of vertical green product diversification.

\subsection{Stakeholder Pressure}

The stakeholder is defined as "any group or individual who can affect or be affected by the achievement of the objectives of an organization » (Freeman, 1984, p. 48). Henriques and Sadorsky (1999) identified four categories of environmental stakeholders: regulatory (e.g.governments), organizational (e.g. customers), community (e.g. non-governmental organizations (NGOs)), and the media. Firms that fail to yield to pressure from these stakeholders risk enduring possible loss; onthe contrary, systematic management of firms' relationship with stakeholders can benefit organizations in improving their environmental and financial performance (Darnallet al., 2008; Dangelico and Pujari, 2010; Harrisonet al., 2010). As a response to stakeholders' environmental demands, firms'green product development strategies are the interactive results between stakeholder power and manager perceptions on stakeholders' salient environmental preference (Mitchellet al., 1997; Henriques and Sadorsky, 1999; Banerjee, 2001). The internal heterogeneity of stakeholder groups and the resourcedependence dynamics result in stakeholders having different levels of influence on the corporate green innovation decision (Bansal, 2005; Kassinis and Vafeas, 2006). It is critical to identify the leading green stakeholders and appraise their pressure when studying the environmental response patterns of firms (Hart, 1995; Murillo-Lunaet al., 2008). We argue, in 
this study that different stakeholders have heterogonous effects on the decision of horizontal and vertical green product development. A conceptual model is shown in Figure 1.

Figure1. Conceptual model.

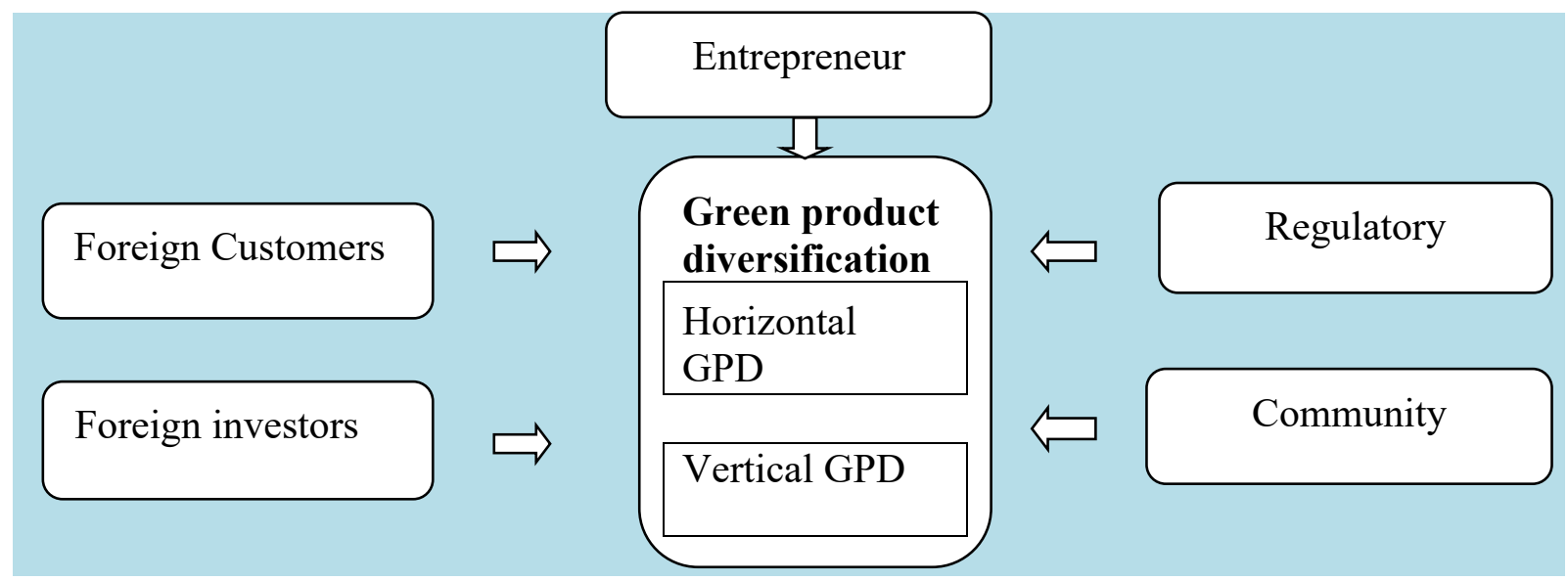

\subsection{Entrepreneur}

The approach of SMEs to corporate environmental responsibility (CER) is different from that of large firms in that it is personalized and informal. SMEs' engagement with CER reflects the values of their owners and the needs of their community, since their engagement results more from a genuine concern for the community and the environment than the anticipated business benefits (Panwar and al., 2016). The Top Management Team has an important role in defining the environmental orientation of the firm, since their values and environmental orientation determine to a great extent the corporate responsibility assumed and the environmentally practices implemented by the firm (Menon and Menon, 1997). Entrepreneur's values and personal commitment are linked to a more general concern for the environment (Williams and Schaefer, 2013), especially in SMEs where the manager is the main strategic decision-maker (Schaper, 2002). The proactive environmental and social attitude of the entrepreneur can attract, retain skilled employees, investors, customers ... and reduce the risks and thus create favorable conditions for creativity of new product and develop business in the context of an uncertain and competitive market. According to Darnall and Edwards Jr (2006); Stein (2009), with the increasing demand for green products, firms'green products can expand their market share. Green products, especially those having obtained green certification, can provide an environmental assurance for green consumers. Hence, we propose that: 
Hypothesis 1a: Entrepreneur have positive influences on the adoption of horizontal green product diversification.

Hypothesis 1b: Entrepreneur have positive influences on the adoption of verticale green product diversification.

\subsection{Customers}

With the increasing concern about the quality of the natural environment, customers have started to pressurefirms to improve their environmental performance (Christmann, 2004; Wagner, 2007; Darnall et al., 2008; Horbach, 2008; Delmas and Montiel, 2009; Massoudet al., 2010). Pressure from customers may stimulatefirms in adoptingproactive green innovation strategies (Buysse and Verbeke, 2003; Sharma and Henriques, 2005; Murillo-Lunaet al., 2008; Sandhuet al., 2010; Sarkis et al., 2010). These strategies can benefit firms by differentiating their products and thus gaining a competitive advantage. Physically distant customers need reliable signals that indicatefirms' commitment to environmental protection (Kinget al., 2005; Nishitani, 2009). Certified products or environmental management systems can provide reliable information for their production process and products (Zhu and Sarkis, 2004). These certified products and processes are often perceived by firms as the necessity to gain entry into the global market (Christmann and Taylor, 2001; Welchet al., 2002; Christmann, 2004; Zeng et al., 2005; Wu et al.,2007; Nishitani, 2009; Massoudet al., 2010). This leads to the following hypotheses:

Hypothesis 2a: Foreign customers have positive effects on the adoption of horizontal green product diversification.

Hypothesis 2b: Foreign customers have positive effects on the adoption of vertical green product diversification.

\subsection{Foreign Investors}

With the increasingly interdependent economic relationship among between countries, foreign direct investment (FDI) are widely recognized as the key agents in the diffusion of green innovation practices globally, (Christmann and Taylor, 2001; Perkins and Neumayer, 2009; Zenget al., 2009), knowledge and technologies (Gorg and greneway, 2004; Javoreick, 2004; Lin and al, 2009; Du and al, 2009). FDI has a positive impact on the level of product diversification through direct and indirect channels (Iwamato and Nabeshima, 2012). Scalet and Kelly (2010) suppose that CER is the answer for a question of how to differentiate one's product to satisfy investor demand. Such anticipation is probably plausible in 
that investors have a propensity to show willingness to pay a premium for the stocks of firms which are socially responsible (Mishra \& Suar, 2010). Suppliers of capital may prefer to do business with firms exhibiting strong environmental and socialperformance because their cash flows may be perceived to be at less risk and less prone to negative performance (O'Shaughnessy et al., 2007). However, SMEs also tend to be the targets of environmental demands from external stakeholders (González-Benito and González-Benito, 2010) and they face pressure from stakeholders both at home and abroad (Darnall and Edwards Jr, 2006). One of the fundamental differences between large and small firms is their actual access to resources (Ang 1991; Berger and Udell 1998). Small firms often do not have enough financial resources to support their activities and investments and mainly rely on internal sources such as personal savings and retained profits whereas large firms have access to a wider range of resources including equity finance and term loans (Berger and Udell 1998). Next to a lack of financial resources, small firms are considered to lack the knowledge and skills to implement environmental practices, a lack that may be overcome by external support. Empirical studies found that foreign invested firms are more likely to implement proactive environmental innovation strategies (Zenget al., 2005; Albornoz et al., 2009). Therefore, in the light of the above analysis, it is hypothesized that:

Hypothesis 3a: Foreign direct investment (FDI) has positive influence on the adoption of horizontale green product diversification.

Hypothesis 3b: FDI has positive influence on the adoption of vertical green product diversification.

\subsection{Regulations}

Societal concerns over the negative environmental impacts of firms' production process and their products have led to a sharp increase in environmental regulations through out the world (Rugman and Verbeke, 1998). Environmental regulations are an important element in understanding the dynamics of eco-innovations (Pickman, 1998). Regulatory stakeholders play an important role in influencingfirms' adoption of environmental management practices (Christmann, 2004; Delmas and Toffel, 2004; Earnhart, 2004; Backer, 2007; Etzion, 2007; Zhu and Sarkis, 2007; Darnallet al., 2009). Governments can mandate firms to use pollution control technology and reduce their environmental impact (Darnall et al., 2008; Darnall, 2009). They can also encourage firms to implement proactive green process innovation to control the environmental impact of their production process (Johnstone 
and Labonne, 2009). Failure to meet with the demand of regulatory stakeholders leads companies to penalties, fine, lawsuits, and even loss of operating permits (Kassinis and Vafeas, 2006; Sarkis et al., 2010). As a result, firms responding to the demands of regulatory stakeholders may need to commit resources and manpower to control their environmental impacts of the production process. Environmental investments can also benefit firms' own interests. On one hand, proactive environmental production, such as implementation of ISO 14001, can signal to the government their cooperative intents, can improve government's credit to firms, and can ease regulatory burdens (Prakash and Kollman, 2003; Potoski and Prakash, 2004, 2005; Darnall et al., 2008; Delmas and Montiel, 2008). On the other hand, green innovation can also reduce their production costs and/or help expand the markets for their eco-products (Porter and Van der Linde, 1995). Environmental regulations have also been considered a significant determinant of green product diversification (Cleff and Rennings, 2000; Rennings, 2000) as previous studies have identified regulatory pressures as the main determinant of firms' green innovation (Henriques and Sadorsky, 1996; Cleff and Rennings, 2000; Kassinis and Vafeas, 2006; Frondelet al., 2008; Triebswetter and Wackerbauer, 2008; Johnstone and Labonne, 2009). In view of the above, we hypothesize that:

Hypothesis 4a: Firms faced with stronger regulatory pressure are more likely to adopt horizontal green product diversification.

Hypothesis 4b: Firms faced with stronger regulatory pressure are more likely to adopt vertical green product diversification.

\subsection{Community}

Local communities are concerned about firms' ecological and social impacts (Henriques and Sadorsky, 1999; Sharma and Henriques, 2005). Community stakeholders can implement direct or indirect influence on firms'environment strategy (Sharma and Henriques, 2005; Pavlovich and Akoorie, 2010). They can mobilize public sentiment in favor of or against a company's environmental approach (Bennet al., 2009). Firms that fail to yield to this stakeholder pressure risk enduring possible public protests (Hoffman, 2000). In other instances, community stakeholders may publicize information which could persuade consumers to favor the products of competitors that have demonstrated a stronger regard for the environment (Sarkiset al., 2010). Firms' decisions on their operation location at the regional level provide the information for explaining the social pressure experienced by a company (González-Benito and González-Benito, 2010). Responding to community 
stakeholders' demand can improve or maintain relations with the community stakeholders (Raines, 2002; Delmas and Toffel, 2004; Zhanget al., 2008). Furthermore, community stakeholders' power on organizational environmental management practices may vary depending on the community's characteristics (Kassinis and Vafeas, 2006). Community stakeholders' power can be used on the community's characteristics. Their influences are heterogeneous. If an enterprise moves to a poor region, it sees less environmental pressures from the community and vice versa. (González-Benito and González-Benito, 2010). Compared with residents in poor regions, residents in wealthy regions may pay more attention to the non-economic aspects of their living conditions (Frooman, 1999; Pfeffer and Salancik, 2003). However, those residents located in poor regions lack the power to influence corporate policies (Kassinis and Vafeas, 2006). Therefore, residents located in wealthy regions may demand firms to adopt green product as a commitment to the environment (Perkins and Neumayer, 2010). We hypothesize that:

Hypothesis 5a: The higher the income in a geographic community, the higher adoption rate of horizontal green product diversification of firms will be in that community.

Hypothesis 5b: The higher the income in a geographic community, the higher adoption rate of vertical green product diversification of firms will be in that community.

\section{Methodology}

\subsection{Data}

The dataset was based on a survey undertaken by the General Statistics Office (GSO) and the Central Institute for Economic Management (CIEM). This was a survey on the the Vietnam Technology and Competitiveness that has been conducted every year since 2010, concluding with 2014. The General Statistics Office (GSO) conducted the survey of 2600 firms in 10 provinces. Though the choice of the 10 provinces was based on the principle of representation rather than on a random basis, they constitute a reasonable representation of Vietnam in terms of geographic locations, economic, social, and legal indicators. The survey mainly included manufacturing firms and accounting information from 2010 to 2014. We consider an enterprise to be diversifying if it started producing a new product during the past three years (denoted vertical diversification) or if it made significant improvements of existing products (denoted horizontal diversification). Therefore, based on the previous study, the observations were eliminated if the firms concerned had already adopted ISO 14001or eco-label in the previous year. We have added information of regional environmental regulations and regional GDP per capita during this period based on the Vietnam Statistics 
Yearbook and regional environmental management indicators computed by the Vietnamese Academy of Science, and the final data used for analysis in our study is composed of 8156 observations. The questionnaire includes questions on the state of certification of ISO 14001 or eco-label. If firms passed the certification of ISO 14001 or eco-label, they were further asked the year that they had obtained the certification. Once a firm passed the ISO 14001 certification or the eco-label certification, we dropped the observations of the firm after these years.

\subsection{Measurement}

\subsubsection{Dependent variables}

Green product diversification is, for the purpose of this paper, defined at the enterprise level as a production of more than one 4-digit ISIC product whit the greening certification status. We consider an enterprise to be diversifying if it started producing a new product (at the 4-digit ISIC level) during the past tree years (denoted vertical diversification) or if it made significant improvements of existing products (denoted horizontal diversification). We use ISO 14001 and eco-label as proxy variables for product diversification for several reasons. Frei, (1998), Marinova et Altham (2000) reported that ISO 14001 certified companies give higher significance to sustainable product design compared to non-certified ones. Some researchers have reported more successful practices that link product development and/or ecodesign measures within ISO 14001 EMS. Special product oriented EMS projects have been developed in the Netherlands with the aim of embedding ecodesign within firms on a continuous basis, rather than on an individual project basis. Van Berkel et al. (1999) summarized the successful ecodesign projects of Dutch retail and industrial companies that cooperated in a project that resulted in environmental improvements to their products. In addition, the studies of Rehfeld et al. (2007) and Ziegler and Rennings (2004) showed that certification of EMS based on ISO 14001 can have a positive effect on environmental product creations. Hertin et al., 2004; Rennings et al., 2006; Wagner, 2007; 2008; Ziegler and Seijas Nogareda, 2009 further confirmed the link between EMS and news products development. The study of Radonjic ${ }^{2}$ and Tominc (2006) shows that ISO 14001 could lead technical innovation activities and create environmentally friendly products as well. In this way, according to Galvin and Rice (2008), standardization and labeling are perceived as an enabler for innovation by facilitating access to markets and enabling interoperability between new and existing products. Consistent with the above ideas and our definition of horizontal and vertical diversifcation of green products (page 3 and 4), Thus, certification status of ISO 14001 during the period study is used as the proxy variable to 
measure vertical green product diversification (VGPD), and the certification status of ecolabel as the proxy variable to measure horizontal green product diversification (HGPD).

\subsubsection{Independent variables}

\section{Regulations}

Some researchers use a single variable as the proxy for measuring regulatory stringency, such as waste gas emissions data (Prakash and Potoski, 2007; Madsen, 2009; He, 2010), and the environmental-related investments (Kassinis and Vafeas, 2006). Some critics argue that single variable criterion, such as $\mathrm{SO} 2$ emissions, may only reflect the environmental policy in a narrow category rather than the overall stringency of environmental regulations (Xing and Kolstad, 2002). Cagatay and Mihci (2006) constructed a composite index for environmental stringency calculated from multiple variables, such as expenditures on pollution abatement as a percentage of GDP, wastewater treatment as a percentage of population served, treatment and disposal of hazardous waste as a percentage of generated hazardous waste, etc. In this study, we use a composite index named as Environmental Management Index (EMI) as the proxy of regulatory stringency in each province which scales the following five sub-indices, namely, (1) the implementation state of environmental impact assessment; (2) regime of three concurrences in environmental protection, i.e. the pollutant treatment facility attached to a factory facility should be designed, constructed and put in use concurrently with the factory facility; (3) environmental government employees per thousand persons; (4) the handling rate of environmental complaint letters; and (5) the handling rate of environmental complaint visit. The EMI values of each province, which issued by the National Statistical Indicators System (NSIS) of the General Statistics Office (GSO) provides coordination for data collection between provinces and the national government. The index data come from the Report Study for a Provincial Environmental Performance Index in Vietnam. We argue that the larger the index value of a province, the stricter the environmental regulations in that province will be.

\section{Customers}

In this paper, we employ the variable export to measure the effect of foreign customers on horizontal and vertical green product diversification of SMEs. The variable of export status (EXPORT) measures whether the focal firms have sold their products to foreign markets 
during 2010-2014. The variable EXPORT takes a value « $1 »$ if the firm exports in a given year and $« 0 »$ otherwise.

\section{Entrepreneur}

Entrepreneur (ENT) has an important role in defining the environmental orientation of the firm and strategic decision making (Schaper, 2002). A dummy variable that takes the value « $1 »$ when the firm indicates that environmental practices were developed because they were part of the company values, mission, image and other avantage and « $0 »$ otherwise.

\section{Community}

We use per capital income (GDPPC) in each province as the proxy for the community stakeholders' pressure in that province. This proxy captures the heterogeneous capacity of community stakeholders in influencing the adoption of horizontal and vertical green product diversification practices. Data of per capita income was collected from the Vietnam Statistics Yearbook. The variable of GDPPC is calculated using each province's GDP and the total number of population, both coming from the Vietnam Statistic Yearbooks in 2010 to 2014.

\section{Foreign investors}

The presence of foreign investment is measured by the dummy variable (FDI $=1$ represents the presence of FDI from non-vietnamese western countries).

\subsubsection{Control variables}

\section{Industry}

Industrial related factors represent a relevant variable to explain the divergences in firms' environmental performance. Because different industrial sectors have different pollution potentials, firms in different sectors will be subject to different pressures from environmental stakeholders. These industrial characteristics can explain the heterogeneity of firms' green product diversification practices (Banerjeeet al., 2003; Wagner, 2007; GonzálezBenito and González-Benito, 2010).

\section{Firm size}

The different researchers consider that the larger the firms, the more resources and abilities to reduce environmental impacts (Melnyket al., 2003). Hence, firms' size is considered in our study in analyzing firms' decision to adopt green product diversification. 
Based on previous studies (Aragón-Correa, 1998; Melnyket al., 2003; Wagner, 2007; González-Benito and González-Benito, 2010), we use the number of employees as a measurement of firms' size. We distinguish between micro firms (1-9 employees; reference category), small firms (10-49 employees) and medium-sized firms (50-300 employees). This distinction corresponds to the definition of SMEs set by the Vietnamese government and the World Bank.Several studies show that firms' size has a positive effect on firms'environmental activities in general (Melnyket al., 2003; Zhu et al., 2008) and on green product in particular (Rehfeldet al., 2007).

\section{Results and Analysis}

Certification status of ISO 14001 during 2010-2014 is used as the proxy variable to measure vertical green product diversification, and the certification status of eco-label during 2010-2014 as the proxy variable to measure horizontal green product diversification, both as the dependent and dummy variables in the study. Based on the dependent variables, binary discrete choice model is applied. The independent variables include: ENT (entrepreneur), REG (regulation), FDI (foreign direct invetement), GDPPC (GDP per capital income), EXPORT, and SIZE. Except the dummy independent variables, the independent variables are lagged behind by one year to represent the response time to cater for the variables' effects (Nishitani, 2009). Based on the previous study conducted by Christmann and Taylor (2001), the industries with the largest numbers offirms certified for ISO 14001 and eco-label were nominated as the control.

Table 1: Descriptive statistics and correlations

\begin{tabular}{|c|c|c|c|c|c|c|c|c|c|c|}
\hline Variable & Mean & Std.Dev. & 1 & 2 & 3 & 4 & 5 & 6 & 7 & 8 \\
\hline 1 Horizontal & 0.010 & 0.112 & 1 & & & & & & & \\
\hline 2 Vertical & 0.032 & 0.171 & $0.111^{*}$ & 1 & & & & & & \\
\hline 3 ENT & 0.041 & 0.202 & 0.001 & $0.060 *$ & 1 & & & & & \\
\hline 4 REG & 105.9 & 6.670 & 0.012 & -0.020 & -0.032 & 1 & & & & \\
\hline 5 FDI & 0.110 & 0.311 & 0.011 & $0.071^{*}$ & -0.001 & 0.001 & 1 & & & \\
\hline 6 GDPPC & 14023 & 8029 & 0.010 & 0.011 & 0.016 & -0.050 & $0.100 *$ & 1 & & \\
\hline 7 EXPORT & 0.421 & 0.490 & $0.041^{*}$ & $0.062 *$ & $0.060 *$ & -0.031 & $0.150 *$ & $-0.041^{*}$ & 1 & \\
\hline 8 SIZE & 728.1 & 3150 & $0.110^{*}$ & $0.131^{*}$ & 0.024 & 0.042 & -0.020 & $-0.070 *$ & $0.110^{*}$ & 1 \\
\hline
\end{tabular}

$* \mathrm{p}<0.1, * * \mathrm{P}<0.05$. 
The statistics of explanatory variables and dependent variables used for analysis are summarized in Table 1.

Table 1 contains descriptive statistics and correlations for the studied variables. Positive correlations are found between EXPORT and horizontal green product diversification (HORIZONTAL) and vertical green product diversification (VERTICAL). The results preliminarily provide support for Hypothesis 2a and Hypothesis 2b. Furthermore, the significant positive relationship between entrepreneur (ENT) and vertical GPD (VERTICAL) also supports Hypothesis 1b. The significant relationship between FDI and vertical GPD (VERTICAL) provides support for Hypothesis 3b. Significant evidence has not been found for other hypotheses in the correlation analysis.

We use two probit regress models to explain firms' horizontal and vertical GPD. In our regress model, the observation data for all years are pooled, whilst introducing a dummy variable'Year' to control for differences across years. The industrial heterogeneity is controlled by introducing the industry dummy variables. The regress results are shown in Table 2.

Table 2 Probit model of horizontal and vertical green product diversification

\begin{tabular}{lll}
\hline Independent variables & Modele 1 & Modele 2 \\
\hline & Horizontale & Vertical \\
& GPD & GPD \\
\hline EXPORT & $0.278^{*}$ & $0.250^{* *}$ \\
ENT & $(0.162)$ & $(0.110)$ \\
FDI & 0.043 & $0.400^{* *}$ \\
REG & $(0.39)$ & $(0.18)$ \\
& -0.122 & $0.521^{* * *}$ \\
GDPPC & $(0.281)$ & $(0.130)$ \\
SIZE & 0.016 & 0.011 \\
& $(0.025)$ & $(0.014)$ \\
Manufacture of coke and refined petroleum products & 0.001 & 0.002 \\
& $(0.001)$ & $(0.001)$ \\
Manufacture of computer, electronic and optical products & $0.000^{*}$ & $0.000^{* * *}$ \\
Manufacture of chemicals and chemical products & $(0.000)$ & $(0.000)$ \\
& -0.174 & -0.180 \\
Manufacture of pharmaceuticals, medicinal chemical and & $(0.659)$ & $(0.469)$ \\
botanical products & 0.091 & 0.228 \\
Manufacture of food products & $(0.384)$ & $(0.206)$ \\
& 0.242 & 0.274 \\
& $(0.276)$ & $(0.188)$ \\
& $0.665^{*}$ & 0.015 \\
& $(0.385)$ & $(0.276)$
\end{tabular}


Manufacture of electrical equipment

Manufacture of electrical equipment

Other manufacturing

$1.012 *$

$(0.401)$

Year-2010

$(0.496)$

Year-2011

$-0.380$

$(0.352)$

Year-2012

Year-2013

Robust standard errors in perentheses

${ }^{*} \mathrm{p}<0.1,{ }^{*} \mathrm{P}<0.05,{ }^{* * *} \mathrm{P}<0.01$

Table 2 reports the parameter estimates together with levels of significance and robust standard errors. Both the Probit regress models show that export-oriented firms have a positive effect on the implementation of horizontal GPD $(\boldsymbol{\beta}=0.278, \mathbf{p}<0.1)$ and vertical GPD ( $\boldsymbol{\beta}=0.250, \mathbf{p}<0.05)$. Hence, Hypothesis $2 \mathrm{~b}$ is moderately supported and Hypothesis $2 \mathrm{a}$ is hardly supported. Entrepreneur and foreign investors have heterogeneous effects on the implementation of horizontal and vertical GPD.

As shown in Table 2, entrepreneur have a significant effect on vertical GPD $(\boldsymbol{\beta}=0.400$, $\mathrm{p}<0.05)$. The result supports Hypothesis $1 \mathrm{~b}$. However, its effect on the implementation of horizontal GPD is found not significant $(\boldsymbol{\beta}=0.043, \mathbf{p}>0.1)$; as the result, Hypothesis 1a is not supported. The effects of foreign investors on horizontal and vertical GPD are also heterogonous. Compared to domestic enterprises, foreign-invested enterprises have higher possibility to implement vertical GPD ( $\boldsymbol{\beta}=0.52, \mathbf{p}<0.01)$, and their effect on horizontal GPD is not significant $(\boldsymbol{\beta}=-0.12, \mathbf{p}>0.1)$. This means that public firms are more sensitive to firms' environmental impact during the production process. Since the reform of economic policy, Vietnam opens to foreign investors. It is noted that the private sector share is increasing strongly and is often associated with FDI but the Vietnamese economy remains dual, the public sector is present. Public enterprises absorb $45 \%$ of the country's investment and $70 \%$ of development aid. They seek to innovate their manufacturing process, to implement green 
strategy to be able to face the competition. Contrary to our Hypothesis $4 \mathrm{a}, \mathrm{b}$ and Hypothesis $5 \mathrm{a}, \mathrm{b}$, we have not found any significant evidence for positive influence of GDPPC and REG on both the horizontal GPD and vertical GPD. The stringency of regulations has no significant effect on both the horizontal GPD $(\boldsymbol{\beta}=0.02, \mathbf{p}>0.1)$ and vertcal GPD green $(\boldsymbol{\beta}=0.01, \mathbf{p}>0.1)$. Furthermore, the results suggest that GDPPC has no significant effect on the probability of afirm adopting both horizontal GPD $(\boldsymbol{\beta}=0.00, \mathbf{p}>0.1)$ and vertical GPD $(\boldsymbol{\beta}=0.00, \mathbf{p}>0.1)$.

\section{Discussions}

\section{Internationalization and Environmental Spillovers}

The results indicate that the influence of export on both of horizontal and vertical green product diversification is significant. This supports the hypothesis that international trade improves the diffusion of green innovation practices, which are consistent with the previousfindings that international trade plays a prominent role in diffusing environmentefficient practices (Albornozet al., 2009; Zeng et al., 2009). International trade provides an opportunity for firms located in developing countries to learn about new environmental management practices from their foreign peers (Perkins and Neumayer, 2009; Sarkis et al., 2010). On the other hand, the effect of FDI on firms' green product practices is heterogeneous. Although the effect of FDI on the adoption of vertical green product diversification is significant, the effect of FDI on horizontal green product diversification is not significant. As a proactive green innovation strategy, ISO 14001 plays an important role in integrating the global environmental management of SMEs (Sáez-Martínez and al, 2016). The presence of environmental spillovers from foreign firms as reported in previous studies will leadto the fact that foreign-owned firms are more likely to implement environmental management systems (EMS) (Albornoz et al., 2009; Perkins and Neumayer, 2009). Contrary to ISO 14001, different countries have developed their own green product certification programs, such as the German Blue Angel, the US Green Seal, the NordicCouncil White Swan, the Canadian Environmental Choice, the European Eco-Label and the Japan Eco Mark (Albino et al., 2009). If a firm supplies its products to different countries, it has to certify their products according to different codes at different countries. The localization of certification of green products has set barriers for diffusion of green innovation practices. To avoid this, implementing international standards to encourage mutual recognition of eco-labeling is necessary.

\section{Environmental Regulations and Green product diversification.}


We assume that the relevant drivers influencing the strategic decision are not simply the degree of stakeholders'environmental pressure but the degree to which environmental stakeholder pressure is perceived by managers in charge of strategic decision making (Buysse and Verbeke, 2003; Murillo-Lunaet al., 2008; González-Benito andGonzález-Benito, 2010). Although environmental regulations were the most important factor in environmental defensive behavior offirms, the proactive environmental innovation strategy is mainly determined by the market pressure, mainly from customers and investors. Stringent regulations drive the environmental defensive behavior offirms, which will discourage the implementation of proactive green product practices, such as ISO 14001 certification.

\section{Community Stakeholders and Green product diversification}

Communities are playing increasingly important roles in environmental protection (Liu, 2009) and green product development in developed country. However, the key factors determining firms'green product diversification practices have not been identified in Vietnam. The community stakeholders may worry about the effects of these environmental industrial activities, although some of these causing environmental damages are far from the affected area (González-Benito and González-Benito, 2010); i.e. the pressures from community stakeholders may be cross-regional. The development status of community organizations may be another explanation for the effect of community stakeholders, for example, Vetnam's environmentally oriented NGOs (ENGOs) are still at the infancy stage and their development is constrained by legal and political limitations and so the development of ENGOs mainly confines their operations to environmental management. As a result, both of the regulations pressure and the community pressure cannot play a dominant role in encouraging implementation of the proactive green product diversification strategy.

\section{Concluding Remarks}

In this study, we have explored the different drivers for Vietnamese firms in pursuing horizontal and vertical green green product diversification based on the stakeholders' perspective. Findings reveal that foreign customers play a significant role in bothfirms' horizontal and vertical green product diversification. However, the effect of foreign ownership is heterogeneous, which only demonstrates a significant effect on vertical green product diversification. Contrary to the developed hypotheses, both regulation stakeholders and community stakeholders have no significant effect onhorizontal and vertical green product diversification. Green product diversification is mainly driven by economic 
ormarketing pressures. This study enriches the literature on green innovation and the stakeholder theory.

The results unveil two management implications. First, contrary to some previous studies that firms respond to different stakeholders in a similar way (Murillo-Lunaet al., 2008), firms respond selectively and differently to different stakeholder groups. Although foreign customers exert pressure onfirms to implement both horizontal and vertical green product diversification, general investors only attribute higher weight to vertical green product diversification. In this dynamic environment, firms should adopt differentiation strategy based on their strategic orientation. Exportation-orientedfirms should implement both horizontal and vertical green product diversification. However, domestic-orientatedfirms may only respond to horizontal green product diversification (id significant improvements of existing products).

Ourfindings reveal that export markets are capable of stimulating the diffusion of horizontal and vertical green product diversification. Hence, policymakers can stipulate a prerequisite in their global purchase program. MNEs also can stimulate their network of suppliers to adopt green product practices. As a tool for sustainable development, many countries have established the eco-labeling program which could encourage firms wanting to go internationalization to integrate the eco-labeling programs.

This study has certain limitations. First, we cannot analyze the effect of business environment on the relationship between stakeholders' pressure and the selection of green product diversification strategy. Uncertainty, complexity, and munificence in the business environment may moderate the relationship between the stakeholder pressure and firms' green innovation strategy (Rothenberg and Zyglidopoulos, 2007). Second, although we have controlled firms' size to reduce firms' heterogeneity, other characteristics, such asfirms' age, R\&D intensity, and advertising intensity may also affectfirms' green product decision (Takahashi and Nakamura, 2010). Future empirical analyses could further study the business environment andfirms' characteristics influencing green innovation strategy.

\section{Acknowledgements}

We would like to thank anonymous reviewers for helpful comments. Manh Hung Nguyen acknowledges support from ANR under grant ANR-17-EURE-0010 (Investissements d'Avenir program).

Quang Le Van ( IREEDS), Manh Hung Nguyen (Toulosue School of Economics, INRAE, University of Toulouse Capitole), and Nguyen Viet Thanh (HUNRE) 


\section{REFERENCES}

Albino V, Balice A, Dangelico RM. 2009. Environmental strategies and green product development: an overview on sustainability-driven companies.Business Strategy and the Environment 18:83-96.

Albornoz F, Cole MA, Elliott RJR, Ercolani MG. 2009. In search of environmental spillovers. World Economy32: 136-163.

Amaeshi KM, Crane A. 2006. Stakeholder engagement: a mechanism for sustainable aviation.Corporate Social Responsibility and Environmental Management13 (5): 245-260.

Aragón-Correa JA. 1998. Strategic proactivity and firm approach to the natural environment. Academy of Management Journal41: 556-567.

Armbruster H, Bikfalvi A, Kinkel S, Lay G. 2008. Organizational innovation: The challenge of measuring non-technical innovation in large-scale surveys. Technovation28: 644657.

Babiak A, Trendafilova S. 2011. CSR and environmental responsibility: motives and pressures to adopt green management practices. Corporate Social Responsibility and Environmental Management18:11-24.

Gunningham, N. Corporate Environmental Responsibility; Ashgate: Hampshire, UK, 2009.

Backer L. 2007. Engaging stakeholders in corporate environmental governance.Business and Society Review112:29-54.

Banerjee S. 2001. Managerial perceptions of corporate environmentalism: interpretations from industry and strategic implications for organizations.Journal of Management Studies38: 489-513.

Banerjee SB, Iyer ES, Kashyap RK. 2003. Corporate environmentalism: Antecedents and influence of industry type.Journal of Marketing67:106-122.

Bansal P, Roth K. 2000. Why companies go green: a model of ecological responsiveness.Academy of Management Journal43: 717-736.

Bansal P. 2005. Evolving sustainably: a longitudinal study of corporate sustainable development.Strategic Management Journal26: 197-218.

Baumann H, Boons F, Bragd A. 2002. Mapping the green product developmentfield: engineering, policy and business perspectives.Journal of Cleaner Production10: 409425 .

Baumann-Pauly, D.; Wickert, C.; Spence, L.J.; Scherer, A.G. Organizing corporate social responsibility in small and large firms: Size matters. J. Bus. Ethics 2013, 115, 693705.

Benn S, Dunphy D, Martin A. 2009. Governance of environmental risk: New approaches to managing stakeholder involvement.Journal of Environmental Management90: $1567-$ 1575.

Bessant, J. et Tidd, J. (2007). Innovation and entrepreneurship (1st éd.).

Bos-Brouwers, H.E.J.2010. Corporate sustainability and innovation in SMEs: Evidence of themes and activities in practice. Bus. Strategy Environ. 2010, 19, 417-435. 
Buysse K, Verbeke A. 2003. Proactive environmental strategies: A stakeholder management perspective.Strategic Management Journal24:453-470.

Cagatay S, Mihci H. 2006. Degree of environmental stringency and the impact on trade patterns.Journal of Economic Studies33:30-51.

Capelle-Blancard G, Laguna M. 2010. How does the stock market respond to chemical disasters? Journal of Environmental Economics and Management59: 192-205.

Carrier, C. (2007). Cultiver la créativité et gérer l'innovation dans la PME. Dans Filion J.(dir.), Management des PME: de la création à la croissance (566 p.). Éditions du Renouveau Pédagogique Inc.

Cassells, S.; Lewis, K. SMEs and Environmental Responsibility: Do actions reflect attitudes? Corp. Soc. Responsib. Environ. Manag. 2011, 18, 186-199.

Chen Y, Lai S, Wen C. 2006. The influence of green innovation performance on corporate advantage in Taiwan.Journal of Business Ethics 67: 331-339.

Christmann P, Taylor G. 2001. Globalization and the environment: Determinants offirm selfregulation in China.Journal of International Business Studies32: 439-458.

Christmann P. 2004. Multinational companies and the natural environment: Determinants of global environmental policy standardization. Academy of Management Journal47: 747-760.

Cleff T, Rennings K. 2000. Determinants of environmental product and process innovation Evidence from the Mannheim panel and follow-up telephone survey. In Innovationoriented Environmental Regulation: Theoretical Approaches and Empirical Analysis. Physica-verlag: discovery and invention (455 p.). New-York: Harper Perennial.

Cole MA, Elliott RJR, Shimamoto K. 2005. Industrial characteristics, environmental regulations and air pollution: An analysis of the UK manufacturing sector.Journal of Environmental Economics and Management50: 121-143.

Crowe D, Brennan L. 2007. Environmental considerations within manufacturing strategy: an international study.Business Strategy and the Environment16 (4): 266-289.

Csikszentmihalyi, M. (1997). Where is creativity? In Creativity, flow and the psychology of discovery and invention

Dangelico R, Pujari D. 2010. Mainstreaming green product innovation: Why and How companies integrate environmental sustainability. Journal of Business Ethics 95: 471-486.

Dans Larisa V. Shavinina (éd.), The international Handbook of innovation, Amsterdam, S. pp. 180-190.

Darnall N, Edwards D Jr. 2006. Predicting the cost of environmental management system adoption: the role of capabilities, resources and ownership structure.Strategic Management Journal27: 301-320.

Darnall N, Henriques I, Sadorsky P. 2008. Do environmental management systems improve business performance in an international setting? Journal of International Management14: 364-376.

Darnall N, Seol I, Sarkis J. 2009. Perceived stakeholder influences and organizations'use of environmental audits.Accounting, Organizations and Society34: 170-187.

Darnall N. 2009. Regulatory stringency, green production offsets, and organizations' financial performance.Public Administration Review 69: 418-434. 
De Bakker FGA, Fisscher OAM, Brack AJP. 2002. Organizing product-oriented environmental management from afirm's perspective.Journal of Cleaner Production 10: 455-464.

Delmas M, Montiel I. 2008. The diffusion of voluntary international management standards: Responsible Care, ISO 9000, and ISO 14001 in the chemical industry. Policy Studies Journa 136:65-93.

Delmas M, Montiel I. 2009. Greening the supply chain: When is customer pressure effective? Journal of Economics and Management Strategy 18: 171-201.

Delmas M, Toffel M. 2004. Stakeholders and environmental management practices: an institutional framework.Business Strategy and the Environment13: 209-222.

Ditlev-Simonsen CD, Midttun A. 2011. What motivates managers to pursue corporate responsibility? A survey among key stakeholders.Corporate Social Responsibility and Environmental Management18(1): 25-38.

Durif F, Boivin C, Julien C.2010. In Search of a Green Product Definition. Innovative Marketing, Volume 6, Issue 1.

Earnhart D. 2004. Panel data analysis of regulatory factors shaping environmental performance. The Review of Economics and Statistics 86: 391-401.

Etzion D. 2007. Research on organizations and the natural environment, 1992-present: A review.Journal of Management33: 637-664.

Frondel M, Horbach J, Rennings K. 2007. End-of-pipe or cleaner production? An empirical comparison of environmental innovation decisions across OECD countries.Business Strategy and the Environment16: 571-584.

Frondel M, Horbach J, Rennings K. 2008. What triggers environmental management and innovation? Empirical evidence for Germany. Ecological Economics 66: 153-160.

Frooman J. 1999. Stakeholder influences strategies.Academy of Management Review24: 191-205.

Gallastegui I. 2002. The use of eco-labels: a review of the literature.European Environment12: 316-331.

Georgsdottir, A. S., Lubart, T. 1. et Getz, 1. (2003). The role of flexibility in innovation.

González PDRX. 2009. The empirical analysis of the determinants for environmental technological change: A research agenda.Ecological Economics68: 861-878.

González-Benito J, González-Benito Ó. 2006. A review of determinant factors of environmental proactivity.Business Strategy and the Environment 15(2): 87-102.

González-Benito J, González-Benito Ó. 2010. A study of determinant factors of stakeholder environmental pressure perceived by industrial companies.Business Strategy and the Environment19: 164-181.

Guerin TF. 2009. An assessment and ranking of barriers to doing environmental business with China.Business Strategy and the Environment 18: 380-396.

Hall J, Wagner M. 2011. Integrating Sustainability into Firms' Processes: Performance Effects and the Moderating Role of Business Models and Innovation.Business Strategy and the Environment (in press). DOI: 10.1002/bse.728.

Harrison JS, Bosse DA, Phillips RA. 2010. Managing for stakeholders, stakeholder utility functions, and competitive advantage.Strategic Management Journal31:58-74. 
Hart SL, Ahuja G. 1996. Does it pay to be green? An empirical examination of the relationship between emission reduction andfirm performance.Business Strategy and the Environment5:30-37.

Hart SL. 1995. A natural-resource-based view of thefirm.Academy of Management Review20: 986-1014.

He J. 2010. What is the role of openness for China's aggregate industrial SO2emission: A structural analysis based on the Divisia decomposition method.Ecological Economics69: 868-886.

Henriques I, Sadorsky P. 1996. The determinants of an environmentally responsivefirm: An empirical approach. Journal of Environmental Economics and Management30: 381395.

Henriques I, Sadorsky P. 1999. The relationship between environmental commitment and managerial perceptions of stakeholder importance. Academy of Management Journal42:87-99.

Henriques I, Sadorsky P. 2007. Environmental technical and administrative innovations in the Canadian manufacturing industry.Business Strategy and the Environment16: 119132.

Hoffman AJ. 2000. Competitive Environmental Strategy: A Guide to the Changing Business Landscape. Island: Washington.

Horbach J. 2008. Determinants of environmental innovation--New evidence from German panel data sources. Research Policy37: 163-173.

Huang Y, Ding H, Kao M. 2009. Salient stakeholder voices: Family business and green innovation adoption.Journal of Management \& Organization 15: 309-326.

Jacobs BW, Singhal VR, Subramanian R. 2010. An empirical investigation of environmental performance and the market value of the firm. Journal of Operations Management28: 430-441.

Jiang R, Bansal P. 2003. Seeing the need for ISO 14001.Journal of Management Studies40: 1047-1067.

Johnstone N, Labonne J. 2009. Why do manufacturing facilities introduce environmental management systems? Improving and/or signaling performance.Ecological Economics68: 719-730.

Kammerer D. 2009. The effects of customer benefit and regulation on environmental product innovation: Empirical evidence from appliance manufacturers in Germany.Ecological Economics68: 2285-2295.

Kassinis G. Vafeas N. 2006. Stakeholder pressures and environmental performance.Academy of Management Journal49: 145-159.

King AA, Lenox MJ, Terlaak A. 2005. The strategic use of decentralized institutions: Exploring certification with the ISO 14001 management standard.Academy of Management Journal48: 1091-1106.

Kivimaa P. 2007. The determinants of environmental innovation: The impacts of environmental policies on the Nordic pulp, paper and packaging industries. European Environment 17:92-105. 
Liu X, Yang J, Qu S, Wang L, Shishime T, Bao C. 2011. Sustainable production: practices and determinant factors of green supply chain management of Chinese companies.Business Strategy and the Environment(in press). DOI: 10.1002/bse.705.

Liu Y. 2009. Investigating external environmental pressure onfirms and their behavior in Yangtze River Delta of China. Journal of Cleaner Production17: 1480-1486.

Madsen P. 2009. Does corporate investment drive a'race to the bottom' in environmental protection? A reexamination of the effect of environmental regulation on investment.Academy of Management Journal52: 1297-1318.

Magerholm, A. 2003. Eco-efficiency reporting exemplified bycase studies. Clean Technologies and Environmental Policy. Vol. 5- v3-4. - pp. 232-239.

Massoud MA, Fayad R, Kamleh R, El-Fadel M. 2010. Environmental Management System (ISO 14001) Certification in Developing Countries: Challenges and Implementation Strategies.Environmental Science \& Technology44: 1884-1887.

Melnyk S, Sroufe R, Calantone R. 2003. Assessing the impact of environmental management systems on corporate and environmental performance.Journal of Operations Management21: 329-351.

Menon, A.; Menon, A. Enviro-preneurial Marketing Strategy: The Emergence of Corporate Environmentalism as Marketing Strategy. J. Mark. 1997, 61, 51-67.

Mishra S, Suar D. 2010. Does Corporate social responsibility influencefirm performance of Indian companies? Journal of Business Ethics 95: 571-601.

Mishra, S., \& Suar, D. (2010). Does corporate social responsibility influence firm performance of Indian companies? Journal of Business Ethics, 95: 571-601.

Mitchell RK, Agle BR, Wood DJ. 1997. Toward a theory of stakeholder identification and salience:defining the princile of who and what really counts.Academy of Management Review22: 853-886.

Murillo-Luna JL, Garcés-Ayerbe C, Rivera-Torres P. 2008. Why do patterns of environmental response differ? A stakeholders'pressure approach. Strategic Management Journal29: $1225-1240$.

Nameroff TJ, Garant RJ, Albert MB. 2004. Adoption of green chemistry: an analysis based on US patents.Research Policy33: 959-974.

Nishitani K. 2009. An empirical study of the initial adoption of ISO 14001 in Japanese manufacturingfirms.Ecological Economics68: 669-679.

O'Shaughnessy, K. C., Gedajlovic, E., \& Reinmoeller, P. (2007). The influence of firm, industry and network on the corporate social performance of Japanese firms. AsiaPacific Journal of Management, 24: 283-30

Panwar, R.; Nybakk, E.; Hansen, E.; Pinkse, J. The effect of small firm's competitive strategies on theircommunity and environmental engagement. J. Clean. Prod. 2016, $129,578-585$.

Parthasarathy, G., Hart, R., Jamro E., L. Miner. 2005. Value of sustainability: perspectives of a chemical manufacturing site. Clean Technologies and Environmental Policy. Vol.7- pp. 219-229.

Pavlovich K, Akoorie M. 2010. Innovation, sustainability and regional development: the Nelson/Marlborough seafood cluster, New Zealand. Business Strategy and the Environment19: 377-386. 
Perkins R, Neumayer E. 2009. Transnational linkages and the spillover of environmentefficiency into developing countries.Global Environmental Change19: 375-383.

Perkins R, Neumayer E. 2010. Geographic variations in the early diffusion of corporate voluntary standards: Comparing ISO14001 and the Global Compact.Environment and Planning A42: 347-365.

Pfeffer J, Salancik G. 2003. The External Control of Organizations: A Resource Dependence Perspective. Stanford University Press: California.

Pickett-Baker, J., R. Ozaki. 2008. Pro-environmental products: Marketing influence on consumer purchase decision. Journal of Consumer Marketing. Vol. 25. - v.5. - pp. 281-293.

Pickman HA. 1998. The effect of environmental regulation on environmental innovation.Business Strategy and the Environment7: 223-233.

Popp D. 2005. Lessons from patents: Using patents to measure technological change in environmental models.Ecological Economics54: 209-226.

Porter M, Van der Linde C. 1995. Toward a new conception of the environment competitiveness relationship.Journal of Economic Perspectives 9:97-118.

Potoski M, Prakash A. 2004. Regulatory convergence in nongovernmental regimes? Crossnational adoption of ISO 14001 certifications.Journal of Politics66: 885-905.

Potoski M, Prakash A. 2005. Green clubs and voluntary governance: ISO 14001 andfirms' regulatory compliance.American Journal of Political Science49: 235-248.

Prakash A, Kollman K. 2003. Biopolitics in the EU and the US: A race to the bottom or convergence to the top? International Studies Quarterly 47: 617-641.

Prakash A, Potoski M. 2007. Investing up: FDI and the cross-country diffusion of ISO 14001 management systems.International Studies Quarterly 51: 723-744.

Pujari D, Wright G, Peattie K. 2003. Green and competitive: Influences on environmental new product development performance.Journal of Business Research56: 657-671.

Pujari D. 2006. Eco-innovation and new product development: understanding the influences on market performance.Technovation26:76-85.

Qi GY, Shen LY, Zeng SX, Jorge OJ. 2010. The drivers for contractors' green innovation: an industry perspective.Journal of Cleaner Production 18: 1358-1365.

Qi GY, Zeng SX, Li XD, Tam CM. 2011. Role of internalization process in defining the relationship between ISO 14001 certification and corporate environmental performance.Corporate Social Responsibility and Environmental management(in press). DOI: $10.1002 / \mathrm{csr} .258$.

Raines S. 2002. Implementing ISO 14001-An international survey assessing the benefits of certification. Corporate Environmental Strategy 9: 418-426.

Rehfeld K-M, Rennings K, Ziegler A. 2007. Integrated product policy and environmental product innovations: An empirical analysis.Ecological Economics61:91-100.

Rennings K. 2000. Redefining innovation-eco-innovation research and the contribution from ecological economics.Ecological Economics 32: 319-332.

Rothenberg S, Zyglidopoulos SC. 2007. Determinants of environmental innovation adoption in the printing industry: the importance of task environment.Business Strategy and the Environment 16:39-49. 
Rugman A, Verbeke A. 1998. Corporate strategies and environmental regulations: an organizing framework. Strategic Management Journal 19: 363-375.

Sandhu S, Ozanne LK, Smallman C, Cullen R. 2010. Consumer driven corporate environmentalism: Fact orfiction? Business Strategy and the Environment19: 356366.

Sarkis J, Gonzalez-Torre P, Adenso-Diaz B. 2010. Stakeholder pressure and the adoption of environmental practices: The mediating effect of training. Journal of Operations Management28: 163-176.

Scalet, S., \& Kelly, T. F. (2010). CSR rating agencies: What is their global impact? Journal of Business Ethics, 94: 69-88

Schaper, M. Small Firms and Environmental Management. Int. Small Bus. J. 2002, 20, 235 249.

Shane P, Spicer B. 1983. Market response to environmental information produced outside thefirm. The Accounting Review58: 521-538.

Sharma S, Henriques I. 2005. Stakeholder influences on sustainability practices in the Canadian forest products industry.Strategic Management Journal26: 159-180.

Shen Y, Yao Y. 2008. CSR and Competitiveness in China. Foreign Laguges Press: Beijing, China.

Sons, 476p.

Stein J. 2009. The legal status of eco-labels and product and process methods in the world trade organization.American Journal of Economics and Business Administration1: 285-295.

Takahashi T, Nakamura M. 2010. The impact of operational characteristics onfirms' EMS decisions: strategic adoption of ISO 14001 certifications.Corporate Social Responsibility and Environmental Management17: 215-229.

Tang H. 1998. An integrative model of innovation in organizations.Technovation18: 297309.

Triebswetter U, Wackerbauer J. 2008. Integrated environmental product innovation in the region of Munich and its impact on company competitiveness.Journal of Cleaner Production16: 1484-1493.

Wagner M, Van Phu N, Azomahou T, Wehrmeyer W. 2002. The relationship between the environmental and economic performance offirms: an empirical analysis of the European paper industry.Corporate Social Responsibility and Environmental Management9: 133-146

Wagner M. 2007. Integration of Environmental management with other managerial functions of thefirm: empirical effects on drivers of economic performance.Long Range Planning40: 611-628.

Welch EW, Mori Y, Aoyagi-Usui M. 2002. Voluntary adoption of ISO 14001 in Japan: mechanisms, stages and effects.Business Strategy and the Environment11:43-62.

Williams, S.; Schaefer, A. Small and Medium-Sized Enterprises and Sustainability: Managers' Values and Engagement with Environmental and Climate Change Issues. Bus. Strategy Environ. 2013, 22, 173-186

Wu SY, Chu PY, Liu TY. 2007. Determinants of afirm'sISO14001certification: An empirical study of Taiwan. Pacific Economic Review12:467-487. 
Xing Y, Kolstad C. 2002. Do lax environmental regulations attract foreign investment? Environmental and Resource Economics21:1-22.

Zeng SX, Tam CM, Tam VWY, Deng ZM. 2005. Towards implementation of ISO 14001 environmental management systems in selected industries in China. Journal of Cleaner Production13: 645-656.

Zeng SX, Xie XM, Tam CM, Wan TW. 2009. Relationships between business factors and performance in internationalization: An empirical study in China.Management Decision47: 308-329.

Zeng SX, Xu XD, Dong ZY, Tam VWY. 2010. Towards corporate environmental information disclosure: an empirical study in China.Journal of Cleaner Production18: 1142-1148.

Zhang B, Bi J, Yuan ZW, Ge JJ, Liu BB, Bu ML. 2008. Why dofirms engage in environmental management? An empirical study in China.Journal of Cleaner Production 16: 1036-1045.

Zhang K, Wen Z. 2008. Review and challenges of policies of environmental protection and sustainable development in China.Journal of Environmental Management88: 12491261.

Zhu QH, Sarkis J, Lai KH, Geng Y. 2008. The role of organizational size in the adopotion of green supply chain management in China. Corporarte Social Responsibility and Environmental Management15: 322-337.

Zhu QH, Sarkis J. 2004. Relationships between operational practices and performance among early adopters of green supply chain management practices in Chinese manufacturing enterprises.Journal of Operations Management22: 265-289.

Zhu QH, Sarkis J. 2007. The moderating effects of institutional pressures on emergent green supply chain practices and performance. International Journal of Production Research45: 4333-4355. 